\title{
Understanding of the Traumatic Childhood Experience in Ukrainian Works for and About Children of the Second World War Period
}

\author{
Vitalina Kyzylova ${ }^{1, *}$ Marharyta Vasylieva ${ }^{1}$ \\ ${ }^{1}$ Luhansk Taras Shevchenko National University, Ukraine \\ *Corresponding author.Email: kyzylovavitalina@ukr.net
}

\begin{abstract}
The article contains a complex of Ukrainian works of art for and about children, in which the traumatic experience of childhood caused by the events of the Second World War is accumulated. The main attention is paid to narratives on an autobiographical basis (V. Blyznets, M. Vingranovskyi, Ye. Hutsalo, V. Rutkivskyi, Hr. Tiutiunnyk). Famine trauma and loss trauma (death, forced relocation) are singled out as the most presentable in them. Emphasis is placed on the originality of the narrative style of writers, which helps to accurately convey the traumatic disorders of children, stress caused by fear of death, famine. It was found that famine becomes a psychological dominant, traumatizing the physical and spiritual essence of the main characters. The trauma of famine expresses the problem of its experience by the characters, the author's attitude to it. Features of representation of trauma of loss / death of an animal are characterized. Emphasis is placed on its relevance for children, due to the peculiarities of perception of reality, attachment to the world of nature. The trauma of losing one's home is meaningful. Artistic methods of realization of psychological fractures of children are analyzed. The genre conditionality of selection of the most weighty and expressive facts of representation of traumatic experience is determined.
\end{abstract}

Keywords: World War II, child trauma, trauma of loss, trauma of famine, Ukrainian literature for and about children, prose on an autobiographical basis, genre.

\section{1. ВСТУП}

Українське суспільство упродовж ХХ століття пережило чималу кількість катастроф (Перша і Друга світові війни, Громадянська війна, Голодомор, Чорнобильська катастрофа й ін.), що позначилися на колективній свідомості, сформували культурну пам'ять народу. Вони стали джерелом численних травмуючих ситуацій для людей. (У психології під травмами розуміють екстремальні критичні події, ситуації загрози, що потужно й негативно впливають на індивіда та вимагають екстраординарних зусиль для подолання наслідків цього впливу) [17].

Як нова реальність для людини, травма висуває проблему екзистенціальної дилеми життя і смерті, впливає на картину світу особистості, руйнує іiі цілісність, обмежує здійснення самореалізації особистості й ускладнює можливості в задоволенні потреб [18, с. 9]. Травма є ефектом віддалення, затримки, блокади травматичної дії, яку визначає посттравматичний симптом, що зумовлює повторення стресу - у снах, галюцинаціях, ілюзіях тощо. Травма - не лише болісна подія, а й своєрідна трансмісія, тобто відлуння, передача пам'яті про трагедію через покоління, в інші місця й часи [2, с. 17].

Категорія травми науково осмислена у психології 3. Фройдом та його послідовниками (К. Г. Юнг, Ж. Лакан, О. Феніхель, Г. Сельє, О. Черепанова, П. Левін, Д. Калшед, О. Ранк, М. Решетніков та ін.). Грунтовні дослідження учених уводять проблематику травми в офіційний науковий дискурс світової спільноти.

Своєрідним зразком репрезентації травми є художня література, що спостеріг В. Василенко в дисертації "Модифікація травми в українській еміграційній прозі другої половини ХХ століття”. Проаналізувавши дослідження Ф.-Р. Анкерсміта, Е. Доманської, К. Карут та ін., науковець доходить висновку, що "Письмо, яке володіє власним 
способом опрацювання пам'яті, виступає не лише тлом або засобом репрезентації травми, а й спробою діалогу автора 3 читачем, який має виразно терапевтичну, катарсисну функцію” [2, c. 25].

Згідно із теорією 3. Фройда, психічні травми виникають у дитинстві, вони мають надзвичайно “хорошу пам'ять”, a їх жертви страждають переважно від спогадів та патологічних патернів реагування, реалізованих несвідомо [18, с. 14-15]. Емоційна природа дитини спонукає до реакції на життєві зміни (i позитивні, і негативні), що накладає відбиток на іï особистісний розвиток. Напруження, сильні переживання стають причиною дисгармонії у внутрішньому світі дитини, провокують виникнення в неї психічної травми.

Жертвами трагічних подій, що травмують психіку, стають діти під час воєнних реалій. Діти можуть бути свідками артилерійських обстрілів, спостерігати руйнування свого міста чи села, своєї домівки. Вони можуть бачити поранених чи померлих, катування та вбивство, масову загибель людей. Діти можуть зазнавати тяжких втрат, бачити, як зазнають поранення чи помирають члени їхніх сімей та друзі. Діти самі можуть бути поранені $[7$, с. 6]. Це призводить до численних психологічних проблем, що спостережено в наукових працях з психології, котрі спираються на досвід воєнних конфліктів [12].

Друга світова війна, поза сумнівом, - одна 3 найтрагічніших сторінок нашого суспільства, національна трагедія, що не лише забрала життя мільйонів українців, а й позначилася на психологічному здоров’і нації. Травматичний досвід іiі очевидців вмонтовано у психологію сучасного покоління та спроєктовано на прийдешні.

Повоєнна травматична пам'ять трансльована в численну кількість художніх творів українських письменників (В. Близнеця, М. Вінграновського, Є. Гуцала, О. Довженка, Ю. Збанацького, В. Рутківського, Гр. Тютюнника, Б. Харчука, Ю. Яновського та ін.), 3 яких перед читачем постають не стільки самі воєнні катаклізми, а їх сприйняття, концентрація уваги на переживаннях, тому емоційному стані, що супроводжував їх свідків як безпосередніх учасників процесу, та тих, хто був дистанційованим від нього. У них актуалізовано комплекс автобіографічних знань, набутих письменниками упродовж власного життя. Небезпідставною є думка І. Констанкевич, що саме процес автобіографічного письма трансформує життєвий досвід у послідовну внутрішньо несуперечливу історію [11, с. 50].

Тема дитинства часів Другої світової війни в українській прозі другої половини ХХ століття ставала колом наукових зацікавлень В. Базилевського, І. Бойцун, О. Головія, А. Гурбанської, Т. Качак, В. Кизилової, С. Ленської, Н. Резніченко, О. Чепурної та ін. Дослідники звертали свою увагу на питання психологізму й автобіографізму у прозовому доробку зазначених вище українських письменників, його морально-етичну проблематику, специфіку конструювання образів “дітей війни”, вітаїстичні тенденції у творах про дітей періоду Другої світової війни, особливості інтерпретації теми “діти і війна” тощо.

Своєрідність художнього осмислення проблеми дитячої травми, зумовленої подіями воєнного лихоліття, наразі не набула належного осмислення в українському літературознавстві, проте видається актуальною, оскільки відкриває нові грані не лише психології і творчого методу письменника, а й культурно-історичної епохи, дасть змогу розширити вектори вивчення й аналізу українських художніх творів для i про дітей періоду Другої світової війни, задовольнить сучасні запити суспільства в контексті новочасних реалій доби. Актуальність обраної для аналізу теми посилюється військовими подіями на Сході України, що спричинили численні психотравми дітей, які опинилися в зоні бойових дій, зазнали втрат близьких людей, вимушеного переселення тощо.

Мета дослідження - розкрити особливості репрезентації травматичного досвіду дитинства в українських творах для і про дітей періоду Другої світової війни. До уваги взяті різножанрові (оповідання, новела, повість) твори на автобіографічній основі В. Близнеця, М. Вінграновського, Гр. Тютюнника, Є. Гуцала. Концептуального значення в роботі набуває розуміння автобіографічного письма як такого, що не належить конкретній віковій категорії. Це вдалий приклад асиміляції “дорослого” твору рецептивним смакам i вподобанням дитини/підлітка. Вікова відстань між його автором і адресатом є доволі суттєвою, проте особливість дитячого світосприйняття i світорозуміння дозволяє уникати спрощень та ідеологічних кореляцій творів. Автобіографічний елемент у таких творах чітко означений стильовою палітрою, типом моральних колізій, авторським прагненням виразити ставлення до світу $[10$, с. 301]. На 
глибоке переконання, спостереження за прийомами репрезентації того чи того трагедійного факту розширює спектр літературознавчих студій й увиразнює розуміння авторського задуму художнього твору.

\section{2. МЕТОДОЛОГІЯ}

У роботі застосовано загальнонаукові методи аналізу, систематизації й узагальнення матеріалу, що сприяло опрацюванню теоретичних та історико-літературних джерел, які спрямовані на 3'ясування особливостей репрезентації травматичного досвіду дитинства в художніх текстах. Дослідження здійснено 3 урахуванням системного методу щодо осмислення розвитку української прози для дітей про події Другої світової війни; історико-типологічного - 3 метою визначення жанрової специфіки аналізованих творів, їх зіставлення 3 явищами одного історикохронологічного рівня; культурно-історичного щодо з'ясування стильової авторської своєрідності. Важливе значення у дослідженні посідає психоаналітичний інструментарій, що дав змогу осмислити феномен психологічної травми в контексті травматичних подій, джерела й мотиви аналізованих текстів, авторську специфіку моделювання художніх образів, репрезентацію психологічних конфліктів. У роботі залучено прийоми соціокультурного, біографічного, структурного аналізу, що стало важливою умовою для об'єктивних висновків.

\section{3. ДИСкУСІї}

Другу світову війну варто розглядати не як одиничну подію, а як тривалий у часі феномен, що концентрує в собі численні травматичні події, а також досвід різних соціальних і вікових груп та характеризується певними психологічними наслідками. Глобальні катаклізми війни відібрали в дітей батьків, рідних, друзів, позбавили їх безтурботного дитинства. "Що це за діти, що 3 ними поробила війна? Всі наче притоптані до землі, приглушені. Ні галасу, ні сміху, ні тієї біганини $<\ldots>$ Стоять, немов сироти, руки опущені додолу. Або туляться гуртом до причілка, гріються", - такі враження від пережитого свого часу лишилися у згадках В. Близнеця [1, с. 188].

У наративах про Другу світову війну, де художньо осмислено досвід дитинства, можна виділити кілька категорій травми: травма голоду, втрати рідної домівки, смерть близьких людей, бойові дії тощо.

\section{1. Травма голоду}

Трагічні психологічні наслідки, зумовлені травматичним імпульсом, жагою виживання у Другу світову війну, мав голод. В. Огієнко [13] наводить приклад експерименту, проведеного в 1944 p. у лабораторії фізіологічної гігієни Університету Міннесоти. Проєкт мав на меті простежити, які процеси відбуваються із голодними людьми. Науковці фіксували різні фізіологічні і психологічні зміни (обмежена рухливість, дратівливість, набряки в тілі), утім, найбільш цікаві висновки стосувалися реабілітації. Виявилося, що загальне погіршення психологічного стану учасників експерименту спостерігалося навіть після того, як їхнє харчування стабілізувалося. Отже, навіть після припинення голодування його психологічні симптоми тривали, що підтверджує глибокий i тривалий психологічний ефект від голодування.

Результати Міннесотського експерименту свідчать про тривале збереження травматичних симптомів і дозволяють зробити висновок, що згенерований голодом травматичний імпульс продовжує діяти ще довгий час. Невипадково згадки про нього зафіксовано в численних художніх текстах про події Другої світової війни тих письменників, хто або сам пережив цю жахливу трагедію, або знає про неї від членів своєї родини.

У новелі М. Вінграновського "Бинь-биньбинь” осмислено жорстоку сутність війни 3 проєкцією на трагічність долі головного героя. Виразна експресивно-динамічна оповідна манера, що супроводжується спогадами, спостереженнями, тактильно-нюхово-зоровими асоціаціями, досить влучно передає травматичний розлад дитини, іiі стресовий стан, спричинений присутністю німців та румунів у селі, хворобами, постійними обстрілами, страхом бути вивезеним на чужину, смертю, голодом.

За допомогою використання елементів потоку свідомості як екстремальної форми внутрішнього монологу авторові вдалося передати палітру страждань, відчуттів та емоцій головного героя. Він проговорює їх (увесь текст твору - це розповідь головного героя, навіяна смертю телятка, биня, яким він опікувався, ховав від окупантів), намагаючись у такий спосіб абстрагуватись від жахів війни.

Репрезентантом травматичного досвіду дитини в текстовій площині новели стають незавершені речення, фрагментарність думок, відтворення 
дрібних деталей, які закарбувалися в пам’яті. “А тут ще мами десь нема, і вечір не вечір - одні румуни та німці. Та осінь сіра, хоч прикидається ще жовтуватою. Тиф, та руді миші, та води у криниці нема, черпаєш відром одну мокру глину, i мами десь нема. Піду... А тут ще небо якесь не небо, старе і сиве, як баба Рятушнячка. Піду. Але ж куди вже його йти, як і вечір - чи це ще не вечір, але вечір... " [3]. Лаконізм твору, авторська оповідна манера не передбачає безпосереднього зображення воєнних подій, а пропонує як альтернативу переживання героя, спричинених ними. Фіксація травми реалізується засобами повторення одних і тих же слів і фраз: “А тут ще мами нема", "I вечір не вечір", що створює внутрішню напругу.

Уражена пам'ять героя фокусується на постійному голодуванні за часів війни. Невипадково одне із його найбільших бажань наїстися й нагодувати усіх навкруги: “І̆й богу, як буду рости, то виросту хлібом! Отоді вже наїмся. I мама наїсться. I Дмитрик, і Галинка наїсться... бабі Ратушнячці дам та сховаю ще - прийде батько 3 війни, а я йому хліба" [3].

Письменник майстерно відтворює душевний стан хлопця, його найтонші порухи, зумовлені загрозливими змінами в його зовнішньому світі. Репрезентуючи особливості дитячого світосприйняття, автор апелює до минулих часів, 3 цією метою використовує в новелі спогади як єдино можливу втечу від жахіття воєнних реалій. Вони часто пов'язані із улюбленими стравами: “Я люблю, коли ми лежимо на печі, а у печі під нами булькотить борщ. Булькотить-булькотить, а потім засичить. А як засичить, то нас вже немає. Ми вже спимо. I хоч борщу зараз у печі нема, він все одно булькотить мені i сичить" [3]. Їжа стає нав'язливою ідеєю, вона щоразу нагадує про себе й переслідує дитину.

У спогадах повсякчас зринають кавуни, які знайшов у полові, просо, з'їдене мишами, позаторішні гнилиці в саду; їх присутність у текстовій тканині свідчить про неочевидність репрезентації травматичного досвіду, фрагментарність картини воєнної катастрофи. Функціонально-смислове наповнення мають застосовані у творі вигуки (Ого-го, О! О!), звуконаслідувальні слова (Гужжа! Гужжа! Хап, дряп, няв-няв, мань-мань-мань, бинь-бинь, гу-гугу, угай! угай! угай! ня! ня!), що посилюють напруження оповіді, передають емоції дитини, увиразнюють їі страждання.
Жанр новели дав можливість М. Вінграновському продемонструвати здатність репрезентувати травматичний досвід, відмовившись від безпосереднього зображення конкретних воєнних подій, а, вдаючись до прийомів психологізму, зосередити увагу на переживаннях людини, відтворити іiі враження, думки, почуття.

В автобіографічній повісті $\mathrm{B.} \mathrm{Рутківського}$ "Потерчата", яку сам автор означує як “дитячу сповідь для дорослих, які так нічому й не навчилися", описано численні травматичні ситуації часів війни, пов'язані зі смертю, самотністю, окупацією, втратою домівки, конфліктом матері й діда, голодом тощо. Вони постають на тлі осмислення глибоких філософських проблем, відкривають читачеві трагічні сторінки історії українського народу, увиразнюють суспільну атмосферу середини XX століття. У новелістичних замальовках, 3 яких складається повість, оминається фактографічне зображення подій; це, швидше, письменницькі враження від пережитого, зафіксовані тим чи тим епізодом дитинства [9, с. 42].

Які б сцени не описував письменник (втеча від німців, життя в окупації, стосунки з дідом і бабою, пригоди 3 песиком), уражена пам'ять постійно повертається до згадок про вразливі моменти тогочасного життя, надто про голод, що переслідував їхню родину всю війну. Він стає психологічною домінантою дитини, травмує іiі фізичне й духовне єство.

“Але більше думав про те, щоб його поїсти, бо мама приносила з громадського двору лише кілька картоплинок і варила їх з лушпинням" [15, с. 54]. “Тоді я послухав трохи, як бурчить у мене в животі і пошкандибав туди, де лежали мої іграшки” [15, c. 55]. “Зненацька я відчув, що страшенно голодний. Мені аж під грудьми млоїло. Я озирнувся, аби знайти щось таке, щоб його можна було з'їсти” [15, с. 76]. “Тітки витягували зі своїх клумаків всіляку їжу і заходжувалися обідати. $<\ldots>$ А я потроху-потроху підсувався ближче до тіток і при цьому робив вигляд, ніби те, що було в їхніх вузликах, мене зовсім не обходить" [15, c. 109]. Ці та інші фрагменти повісті стали репрезентантами травматичного зламу головного героя. Його уражена пам'ять щоразу маніфестує несприйняття цього стану, накладає відбиток на особистісний та психічний розвиток. Відчайдушні спроби впоратися із життєвими обставинами в міру своїх фізичних і психічних сил виливаються комплексом захисних реакцій (уміння 
дистанціюватися, диференціювати минуле й сучасне) як наслідок вітаїстичного світобачення письменника, його оптимістичної концепції світу.

Найбільше згадок про голодні часи й бажання вдосталь наїстися вміщено в розділі “Горнятко каші”. Справжнім дивом стало для маленького хлопця пряжене молоко, що його принесла одного разу матір додому і зварила маленькому братикові кашу. Звабливі пахощі пряженого молока не давали спокою цілий день. Йому хотілося подивитися на нього: чи це те саме молоко, що було й до війни? Чи все це не сон? Дитина не може впоратися зі своїми емоціями, вони вивищуються над здоровим глуздом, стають нав’язливою ідеєю, яка не дає спокою. “Дивився і мучився. Я знав, що не можна нічого чіпати без маминого дозволу. I якби це було ще при татові, коли майже ніколи не хотілося їсти, я, мабуть, закрив би заслінку і зліз з табуретки. Але..." [15, с. 58]. Хлопець, який упродовж війни не куштував навіть молока, не зміг встояти перед побаченим горнятком манної кашки. Вкрите коричневою шкуринкою, воно стояло на печі і спокушало дитину. Автор згадує всі деталі внутрішньої боротьби роздвоєного себе, немовби виправдовуючись за скоєний злочин. Підтвердженням цього $є$ внутрішній діалогпереконання з численними аргументами, що стали психоемоційним підгрунтям вчинку героя. Природне фізичне бажання дитини зрештою перемагає здоровий глузд; хлопець дає обіцянку собі, що з'їсть лише скоринку, а кашу залишить молодшому братові. "I рука моя потягнулася до ложки... А тоді я вже й не пам'ятаю, як воно так трапилося, що в горнятку нічого не лишилося. Хіба що трохи кашки пристало на денці” [15, c. 60].

Докори сумління за скоєний “злочин” переслідували хлопця весь день. Йому, зрештою, стало страшно від усвідомлення того, що братик лишиться голодним. Драматизм ситуації посилюється згадками про фізичне насилля: мати вперше в житті відлупцювала хлопця. "Більше я нічого не встиг сказати. Мама однією рукою схопила мене за комір сорочки, а другою заходилася ляскати по попі. <..> Я теліпався в маминих руках, мов шкідливе кошеня. Мені аж забило подих, бо це вперше мама давала мені лупки!" [15, с. 61-62]. Розпач головного героя загострюється усвідомленням того, що за скоєний вчинок і матір, і батько (коли повернеться 3 фронту) перестануть його любити. Усе це викликає душевні страждання і тривогу в дитини.
Зважаючи на той факт, що голод - це тяжке психологічне потрясіння для людини, стає дедалі очевиднішим факт психологічної потреби індивіда проговорити його, вербалізувати. Х. Рутар небезпідставно вважає, що художня література стимулює автора до пригадування, порівняння та зберігання інформації [14, с. 295].

В автобіографічних повістях Гр. Тютюнника “Облога", "Климко", "Вогник далеко в степу" міститься чимало епізодів-згадок з його голодного життя, позначених численними болючими фактами тогочасних реалій. Вони - як фантомний біль щоразу нагадують про себе й переслідують письменника.

“Від картоплі стає тепліше, a іiї пахощі степові, осінні, довоєнні - паморочать голову, і ні про що не хочеться думати, крім одного: коли б то більше було їі, картоплі...” [20, с. 210]; “...я вже не їв, а тьопав, паленіючи від сорому, що не здатен стримати себе: мені здавалося, що всі дивляться, як я похапки ковтаю, і від того я давився, кашляв, утирав сльози...” [20, с. 225]. Малий Харитон (“Облога") часто згадує довоєнне життя, намагаючись в такий спосіб втекти від сумних життєвих реалій. Там, у минулому, - звична зона дитячого комфорту: матір і батько, жива бабуся, поруч 3 якими відчуває себе захищеним, мальовничі краєвиди рідного села, вдосталь їжі.

I хоча Гр. Тютюнник оминає в повісті батальних сцен війни, мовить здебільшого про життя й виживання на війні, а не про смерть, оберігаючи й захищаючи в такий спосіб від неї читача, усе ж, в авторській свідомості (а відтак, і в свідомості головного героя-дитини) вона постає як трагедія масштабного виміру, що охопила всіх і все навкруги, зруйнувала долі мільйонів. "Колона - попереду неї йшло кілька військових - швидко наближалася: старі, молоді, високі, низенькі люди; усміхнені, похмурі, ніякі обличчя; куфайки, кожухи, діжурки, злинялі брезентові плащі, нацуплені поверх теплої одежі; білі, чорні, однокольорові, смугасті, з рядна, торби - рип, рип, рип сніг під ногами” [20, с. 247]. Такою хлопець бачить війну; його погляд хаотично фіксує вік, вирази облич людей, що йдуть на фронт, їхні речі - вони такі різні й водночас однакові, оскільки поєднані спільною трагедією. Психоемоційний дисбаланс Харитона репрезентовано посиленою фрагментацією зовнішнього вигляду, окремих прикмет образів, відбиття у свідомості не реальних явищ і фактів, а асоціативного їх сприйняття.

Головний герой повісті Гр. Тютюнника “Климко”, аби пережити окупаційне лихоліття, 
вирушає до Слов'янська по сіль. Юний герой опиняється на межі виживання, гартується злиднями, голодом, намагається поводитися, як дорослий, але все одно залишається дитиною. “Климко розворушив палицею багаття - 3 нього викотилося дві чорні, як вугілля, картоплини. Шкірка на них так пригоріла, що аж відстряла од серединок, рожевих та пахучих. Климко швидко зжував їх, забувши навіть, що в нього є сіль. I тоді йому так схотілося їсти, що сльози самі виступили на очах. Він повитрушував з кутиків у кишенях діжурки крихти від сухарів, легенько видмухнув 3 них остюки та солом'яну потеруху і ще трохи поласував" [19, с. 268]. Голод психологічно знищує, фізично паралізує Климка; він пригнічений інстинктом самозбереження. Репрезентація фактів голодного життя героя увиразнює не лише проблему “переживання" травми персонажем, а й авторське ставлення до неї. Жанр повісті дає Гр. Тютюннику можливість подати більше подробиць, яскравіше передати спектр емоцій головного героя.

\section{2. Травма втрати}

Т. Гундорова, досліджуючи травматичний досвід у постколоніальному суспільстві, твердить, що "травми - це не лише жахливе, що вривається в життя, а й утрата (курсив наш. - B. К.), що має значний емоційно-психологічний ефект, коли фактично сам суб'єкт стає архівом втрати, місцем, де зберігається пам'ять про травму <..> втрачений об'єкт стає частиною суб'єкта і продовжує існувати в ньому як “інший”, упливаючи на самовідчування, орієнтацію у світі, етичні й культурні цінності” [5, с. 15].

Травма втрати може бути пов'язана із рідною домівкою, батьківщиною, державою (в широкому розумінні), рідною людиною (загибель батька чи матері, друга, брата, сестри, просто людини, яку дуже добре знав), смертю тварини, до якої був сильно прив'язаний. Останнє надто поширене саме в літературі, адресатом якої $є$ дитина чи підліток, що зумовлене запитами реципієнтів, їх особливим психофізіологічним сприйняттям дійсності, прив'язаністю до світу природи, потребою у спілкуванні з тваринним світом, на чому неодноразово наголошували дослідники літератури для дітей та юнацтва, іiї специфіки $[4 ; 8]$.

В аналізованій вище новелі М. Вінграновського “Бинь-бинь-бинь” трагедією для героя стала загибель маленького телятка, якого він так пильно оберігав від фашистів. У "Первінці" письменник акцентує увагу на корові, яку хлопець придбав на міському базарі у перші дні після визволення від фашистів, аби та годувала їхню родину. Утім головне для нього - не кількість іiі молока, а теплі ласкаві очі, роги віночком; дитина пильно доглядає за твариною, оберігає на шляху додому. В. Рутківський у “Потерчатах" твердить про психологічний злам хлопця від загибелі найкращого друга, песика, який перейняв на себе фашистську кулю, аби врятувати дитині життя: “І тоді я впав біля найближчого куща і 3 моїх очей полилися рясні сльози. Крізь них бачився мені песик < .. > Це ж він... не побоявся...життя віддав за мене" [15, с. 121].

Климкові в повісті Гр. Тютюнника доводиться двічі пережити смерть близької людини: у довоєнні часи та на початку війни. Автор не акцентує особливої уваги на смерті батьків юного героя в ранньому дитинстві, проте апелює до емоційної сфери хлопчика, розкриває внутрішній стан дитини після втрати дядька Кирила (єдиної натоді рідної людини): “Климко цілу ніч проблукав тоді на станції, вслухаючись у далекі злякані гудки паровозів, але так і не почув серед них знайомого. Він був один на весь світ - гудок дядькового ФД, - і Климко впізнав би його серед тисячі... <..> На кладовищі Климко вже не плакав, а лише здригався від холоду в грудях і хрипко зітхав” [19, с. 262]. Ця подія стимулює травматичний злам дитини, порушує гармонію у іiі внутрішньому стані.

Тема втрати рідного дому, еміграції та долі людей, що в силу різних обставин змушені покинути рідні краї, стала однією з центральних у творчості Т. Бордуляка, Б. Лепкого, П. Майорського, В. Стефаника, I. Франка, А. Чайковського, Е. Андісвської, У. Самчука та iн., що детально розглянуто Г. Скуртул [16]. Дослідниця наголошує на ii актуальності в українській літературі, тяжкій психологічній травмі людей, що покинули рідну землю внаслідок економічних проблем, військових дій, політичних утисків та репресій. Значною мірою це пов'язано 3 особливостями менталітету українського народу, який віддавна був схильний до осілості, прив'язаний до землі. Відтак, втрата рідної домівки, рідного краю, відрив від свого коріння справжня трагедія для людини, втрата іiі життєствердної основи.

Головний герой "Потерчат” В. Рутківського страждає від усвідомлення того, що вони з матір'ю змушені були покинути рідну хату, своє село, аби врятуватись від німців; його постійно переслідує 
емоція страху, бажання бути пригрітим i приголубленим рідними: "Мене охопили розпач i жах, і безнадія, і розпука" [15, с. 77].

Залишившись зовсім одним, Харитон (“Облога") з тонким щемом згадує їхнє з бабусею мирне життя, їхню домівку: “Як я сюди потрапив? Чого? Адже я десь там, у своєму селі, де кожна бур'янина мені знайома, кожен клапоть землі. $<\ldots>$ Коли те було - сьогодні, вчора чи вічність тому? Як і навіщо я тут опинився, коли десь там, далеко-далеко, моя хата, жовта акація, бабусина могила на піщаному Чебрецевому бугрі, напроти розлогої сосни з відломленою верхівкою?.. " [20, c. 209-210].

Особливої уваги у сценах 3 минулого Гр. Тютюнник надає описові природи. Вона, на глибоке переконання письменника, - той органічний світ, в якому людина відчуває себе комфортно й захищено. Ретроспективні згадки змінюються тяжкими роздумами героя. "Я зі страхом відчуваю, як десь глибоко в душі зав'язується й росте вже знайомий, звіданий мною мулкий сум і втома від цього печального сонця та гайворонячих тіней на ньому, а ще від безсилля збагнути, що коять дорослі” [20, с. 219]. Герой не може прийняти той факт, що всі трагедії, які йому доводиться переживати (смерть, голод, розруха, зруйновані села), спричинені людьми, він постійно замислюється над питанням: “Навіщо?”. Утім, відповіді на нього так і не знаходить.

Одним із репрезентантів травми, пов'язаної із втратою рідної домівки в українській художній літературі для і про дітей є Є. Гуцало. В оповіданні "Біженці" автор осмислює їі на прикладі життя маленької родини - Фросини Ільківни та іiї двох малих дітей.

“Біженців через село пройшло... Важко сказати, скільки їх пройшло,- але, мабуть, не так мало, щоб про це забути. Не так мало, якщо й тепер, коли заплющити очі, встають перед тобою змарнілі лиця тих, кого війна й голод вигнали 3 рідних домівок, погнали в світи шукати якогось затишного пристановиська, наче можна було його знайти; встають перед тобою благальні погляди людей, що випрохують шматок хліба, картоплину, крихітку ласки, тепла" [6]. Такими постають у згадках дитинства люди, що трапилися на життєвій дорозі головного героя твору. Автор зображує епізод із життя однієї родини, утім, дає зрозуміти, що ця проблема стала типовою. Невипадково показує й широкий загал - рух великого потоку людей, дає зрозуміти читачеві, що цей процес став масовим явищем за часів воєнного лихоліття.

Є. Гуцало психологічно переконливо передає глибокий стрес біженців, стани й відчуття тих, хто зустрічався їм на своєму шляху: “...страх, подих невідомого, невтолиме бажання певнішого місця, безпечного. Жалко було дивитись на них: кожен, хоча й прив'язаний до клаптика землі, до власного порога, впізнавав у їхній долі - свою" [6]. Маленького хлопчика (розповідь у творі йде від першої особи) вразили обличчя людей, в яких немає життя, а лише біль, скорбота, відчуття безвиході, приреченості й бажання відігріти свою душу. Голодні, напівроздягнені, Аполлон і Ксеня виглядали безпорадними й незахищеними в очах жителів села. Психологічна травма, яку переживають діти, стає перешкодою їхньої адаптації в новому середовищі. Вони залякані й не йдуть на контакт 3 сільськими хлопцями й дівчатами, остерігаються їх.

Проблему вимушеного переселення в оповіданні Є. Гуцала репрезентовано двопланово: 3 одного боку, як трагедію людей, які втратили свою рідну оселю, рідний край, з іншого - як біль свідків цієї трагедії, жителів села. Вони мало чим можуть допомогти: голод, розруха, зубожіння, безробіття стали для них тяжкою реальністю, і це накладає відбиток на психологію людини, гнітить iii, посилює переживання. Травма, що іiі отримують селяни-свідки внаслідок контакту з біженцями, в оповіданні не стає предметом оповіді, утім спрямовує іiі у відповідному руслі, запрограмовує дії і вчинки дорослих селян та їхніх дітей.

Сільські діти спочатку просто 3 цікавістю спостерігали за Аполлоном і Ксенею, заглядали в шибку хати, де вони зупинилися. Їх дивувала така поведінка брата й сестри. Зрештою, дізнавшись про зникнення матері (Фросина Ільківна повідомила, що смертельно хвора й полишила їх, аби не бути тягарем), вони намагаються чимось зарадити, допомогти, розважити. Особливо цим переймається головний герой твору. Хлопець приносить молока Аполону й Ксені, зігріває їхні душі своїм теплом і любов’ю. “Я все 3 більшою й більшою ніжністю дивився на Ксеню. Вона була така беззахисна й квола, що хотілося погладити іiї по голові, сказати щось добре й ласкаве... " [6].

Стани дітей, травмованих життєвою ситуацією, їх почуття знаходять реалізацію у прийомах психологізму, що їх застосовує автор (внутрішнє мовлення, невласне пряма мова тощо); вони фіксують глибинні психофізіологічні процеси, що пов'язуються з чуттєвими переживаннями автора, 
персонажа і проєктуються на реципієнта, який стає 3 ними єдиним цілим. Особливо зворушливим стають розповіді про іграшкового Діда Мороза, колись подарованого хлопцеві військовим лікарем. Цю дорогу серцю іграшку дитина, не роздумуючи, дарує Ксені, аби тільки побачити радість в її очах.

Терапевтичний ефект мала й подарована навесні ялинка, вбрана головним героєм новорічними прикрасами. “Коли після обіду я приніс ялинку в Макарову хату, то ні Ксеня, ні Аполлон спочатку нічого не зрозуміли. Але потім обоє зраділи. Щоправда, зразу зраділа Ксеня, а потім, дивлячись на неї, і брат. Вона посадовила під ялинкою Діда Мороза й почала кружляти навколо неї. Щось співала і все крутилася, крутилася, а ми з Аполлоном спостерігали” [6]. Ця сцена посилює емоційно-експресивний настрій твору, увиразнює позитивні риси головного героя.

Фінал оповідання виписано в оптимістичних тонах: родина головного героя твору наважується забрати дітей до себе, мати вилікувалась і повернулась до дочки й сина, від родичів надійшов лист про початок відбудови рідного села.

Як бачимо, втрата дому, зустріч 3 новими життєвими ситуаціями (голод, холод, тимчасова втрата матері) стали серйозним випробуванням для дітей у часи Другої світової війни. Адаптуватися у стресовій ситуації Аполлону i Ксені допомагають люди, що трапилися на їхньому життєвому шляху. Їхня небайдужість, любов і милосердя допомагають зцілити травму, подолати відчуженість, депресію, психоемоційний дисбаланс.

Жанр оповідання потребував від автора відбору небагатьох, але найбільш вагомих i виразних фактів, щоб розкрити провідні риси характеру персонажів, передати читачеві їх емоційні стани, викликати в нього відповідну реакцію на зображення травматичних станів i стресових ситуацій. Письменник не зациклюється на достовірності історичних реалій (в оповіданні відсутні конкретні часо-просторові координати), не виносить вироків, а концентрує увагу на трагічному факті в житті дітей як причини їхнього психологічного каліцтва.

\section{4. ВИСНОВКИ}

Як бачимо, в сучасній гуманітаристиці студіювання проблем травматичного досвіду особистості стає щодалі актуальнішим, що зумовлено світовими глобальними катаклізмами.
Надто це стосується українського суспільства, коли реалії новочасної доби спонукають до різноаспектного осмислення цього явища на просторі суспільних зрушень минулого (війни, голодомор, чорнобильська катастрофа тощо) та трансляції травматичного досвіду в сучасний контекст. Дедалі активніше в цьому плані заявляє про себе художня література, яка має широкий діапазон можливостей осмислення травми; пам'ять автора стає в цьому випадку не лише джерелом травматичного досвіду, а і його продуцентом.

У нашій розвідці розглянуто комплекс українських художніх творів для і про дітей, в яких акумульовано травматичний досвід дитинства, спричинений подіями Другої світової війни. Діти, на глибоке переконання, стають особливо вразливими щодо трагічних подій, що призводить до численних психологічних проблем. У наративах на автобіографічній основі виразно артикулюються травма голоду, травма втрати 3 низкою тематичних ракурсів: втрата як смерть (близької людини, тварини), втрата рідної домівки (вимушене переселення).

Травма голоду розглянута на прикладі новели М. Вінграновського "Бинь-бинь-бинь", автобіографічних повістей В. Рутківського "Потерчата", Гр. Тютюнника "Облога". Наголошено на виразній експресивно-динамічній оповідній манері М. Вінграновського, що допомагає влучно передати травматичний розлад дитини, іiі стресовий стан, спричинений страхом смерті, голодом. Автор відмовляється від безпосереднього зображення воєнних подій, натомість концентрує увагу на переживаннях людини, відтворенні їі вражень, думок, почуттів. Для головного героя "Потерчат" голод стає психологічною домінантою, травмує фізичну й духовну суть. Намагаючись подолати життєві труднощі, він «підключає» захисні реакції, зумовлені вітаїстичним світобаченням, оптимістичною концепцією світу. Харитон (“Облога”) від трагічних життєвих реалій втікає в минуле, у світ природи. Там він відчуває себе захищеним. Травма голоду увиразнює проблему іiі “переживання” персонажами, авторське ставлення до неї. Жанр повісті дає можливість подати більше подробиць, яскравіше передати спектр емоцій героїв творів.

$\begin{array}{lrr}\text { Травма } & \text { втрати/загибелі } & \text { тварини } \\ \text { (М. Вінграновський, } & \text { В. Рутківський) } & \text { надто }\end{array}$ актуальна для дитячої аудиторії як результат особливого сприйняття дійсності, прив'язаності до 
світу природи, потреби у спілкуванні з тваринним світом.

Менталітет українця зумовлює травму втрати рідної домівки, що переживається як трагедія, психологічний злам. У “Біженцях" Є. Гуцала вона показана двопланово: очима людей, що втратили iii, та свідків цієї трагедії. Стани травмованих дітей реалізовано прийомами психологізму, що увиразнюють авторські переживання. Жанр оповідання зумовив відбір найбільш вагомих i виразних фактів репрезентації травматичного досвіду. Трагічний факт розглянуто письменником як причину психологічного каліцтва дитини.

Аналіз українських художніх творів для і про дітей, в яких зафіксовано авторський травматичний досвід періоду Другої світової війни, свідчить про переживання іiї як глибокої трагедії, що зруйнувала долі мільйонів людей. Специфіка його репрезентації взалежнена письменницьким світовідчуттям, авторською стильовою манерою, жанровою специфікою твору.

Проведене дослідження накреслює перспективи подальших наукових студій, що можуть бути пов'язані із осмисленням різновидів дитячої травми, механізмів іiі дії та способів репрезентації в новітніх українських творах для i про дітей, зіставленням української та зарубіжної літератур з означеної проблеми.

\section{REFERENCES}

[1] V.S. Blyznets, Old Bell. Selected works, Veselka, 1983.

[2] V.S. Vasylenko, Modification of trauma in Ukrainian emigration prose of the second half of the 20th century, PhD Dissertation, National Academy of Sciences of Ukraine, 2016.

[3] M. Vinhranovskyi, Byn-byn-byn. https://www.ukrlib.com.ua/books/printit.php?tid $\underline{=5143}$

[4] U.S. Hnidets, Specifics of communication in literature for children and youth (based on modern German prose), PhD Dissertation, V.I. Vernadsky Taurida National University, 2008.

[5] T. Hundorova, Transit culture. Symptoms of postcolonial trauma: articles and essays, Hrani-T, 2012.

[6] Ye. Hutsalo, Refugees. https://www.ukrlib.com.ua/books/printit.php?tid
$=5222$

[7] O. Chernenko, M. Lemyk, K. Yavna, Children and war: learning healing techniques, Manuskrypt, 2016.

[8] V. Kyzylova, Literature for children and youth: artistic specifics, tendencies of interpretation, Actual problems of Ukrainian literature and folklore 17 (2012) 10-18.

[9] V.V. Kyzylova, Vitaistic tendency in the prose about children during the period of World War II, Scientific Journal of International Humanitarian University 15(1) (2015) 41-44.

[10] V.V. Kyzylova, Art specifics of Ukrainian prose for children and youth of the second half of the 20th century, Vyd-vo DZ "LNU imeni Tarasa Shevchenka", 2013.

[11] I.M. Konstankevych, Ukrainian prose of the first half of the 20th century: autobiographical discourse, Vezha-Druk, 2014.

[12] M.I. Krasnokutskyi, Ya.O. Ovsiannikova, Psycho-traumatic experience of children: the main stages of psychological care, Scientific Journal of Kherson State University 1(2) (2018) $56-61$.

[13] V. Ohiienko, Post-traumatic stress disorder and collective trauma in the personal narratives of Holodomor witnesses. https://cutt.ly/FbB7iTL

[14] Kh. Rutar, Injured or mythologized memory? (Based on the novel "Tango of Death" by Yurii Vynnychuk), Modern problems of linguistics and literary criticism 23 (2018) 294-298.

[15] V. Rutkivskyi, Poterchata, Navchalna knyha Bohdan, 2013.

[16] H.S. Skurtul, Artistic understanding of emigration in Ukrainian prose of the last third of the XX - beginning of the XXI century, Extended abstract of PhD Dissertation, Borys Grinchenko Kyiv University, 2015.

[17] N.V. Tarabrina, Workshop on the psychology of post-traumatic stress, Piter, 2001.

[18] O.L. Turynina, Psychology of traumatic situations, Personal, 2017.

[19] H.M. Tiutiunnyk, Klymko. Selected works, Hramota, 2008.

[20] Hr. Tiutiunnyk, Obloha. Death of a gentleman, Makhaon - Ukraina, 2001. 